\title{
Venous drainage from the tail of the pancreas to the lienal vein and its relationship with the distal splenorenal shunt selectivity ${ }^{1}$
}

\author{
Drenagem venosa da cauda do pâncreas para a veia lienal e sua relação com a seletividade da \\ anastomose esplenorrenal
}

\author{
Cláudio Piras ${ }^{\mathrm{I}}$, Danilo Nagib Salomão Paulo", Isabel Cristina Andreatta Lemos Paulo ${ }^{\mathrm{III}}$, Hildegardo Rodrigues ${ }^{\mathrm{IV}}$, Alcino Lázaro \\ da Silvav
}

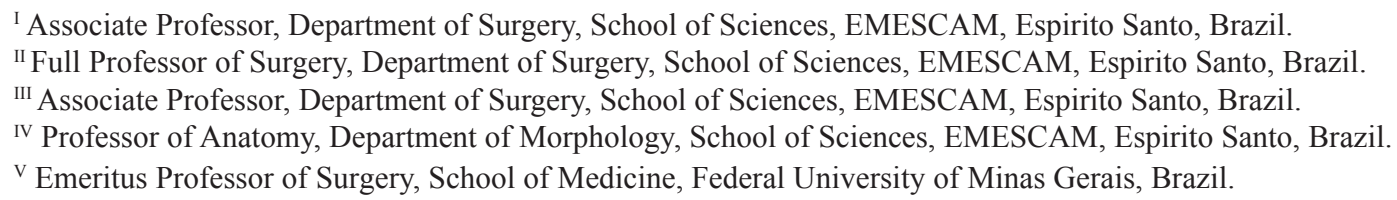

\begin{abstract}
Purpose: To identify the veins draining from the pancreatic tail to the lienal vein and its possible relationship with the loss of the distal splenorenal shunt selectivity. Methods: Thirty eight human blocks including stomach, duodenum, spleen, colon and pancreas, removed from fresh corpses, were studied with the replenish and corrosion technique, using vinilic resin and posterior corrosion of the organic tissue with commercial hydrochloric acid, in order to study the lienal vein and its tributaries. Results: The number of veins flowing directly to the splenic vein varied from seven to twenty two $(14.52 \pm 3.53)$. Pancreatic branches of the pancreatic tail flowing to the segmentary veins of the spleen were found in 25 of the anatomical pieces studied $(65.79 \%)$. These branches varied from one to four, predominating one branch $(60 \%)$ and two branches (24\%). Conclusions: In $65.79 \%$ of the anatomical pieces studied, the veins of the pancreatic tail flowed in segmentary branches of the splenic vein. These branches could be responsible for the loss of distal splenorenal shunt selectivity. The complete disconnection of the pancreatic tail could increase the selectivity in this procedure.
\end{abstract}

Key words: Hypertension, Portal. Surgery. Splenic Vein. Anastomosis, Surgical.

\section{RESUMO}

Objetivo: Identificar as veias da cauda do pâncreas afluentes da veia lienal e a possível relação destes ramos com a perda de seletividade da derivação esplenorrenal distal. Métodos: Foram estudadas 38 peças humanas, retiradas de cadáveres, contendo estômago, duodeno, baço, cólon e pâncreas, utilizando-se a técnica de repleção vascular com resina vinílica e posterior corrosão do tecido orgânico com o objetivo de se estudar o molde vascular da veia lienal e seus afluentes. Resultados: O número de veias afluindo diretamente para a veia esplênica variou de sete a vinte dois (MA 14.52 33.53 ). Ramos pancreáticos da cauda do pâncreas afluindo para as veias segmentares do baço estavam presentes em 25 das peças estudadas (65,79\%). Estes ramos variaram de um a quatro, predominando um ramo (60\%) e dois ramos (24\%). Conclusões: Em 65,79\% das peças veias da cauda do pâncreas desembocavam em ramos segmentares da veia esplênica. Estes ramos poderiam ser responsáveis pela perda de seletividade da derivação esplenorrenal distal e a esqueletização completa da cauda do pâncreas poderia aumentar a seletividade neste procedimento.

Descritores: Hipertensão Portal. Cirurgia. Veia Esplênica. Anastomose Cirúrgica.

${ }^{1}$ Research performed at the Anatomy Laboratory, Department of Morphology, School of Science (EMESCAM), Vitoria-ES, Brazil.

\section{Introduction}

The increase in the portal system pressure leads to the formation of varices in esophageal and gastric region ${ }^{1,2}$. Liver illness responsible for the development of portal hypertension has an evolutionary and irreversible nature. Among the used surgical procedures in the treatment of the portal hypertension, the venovenous anastomosis had been used with the objective of reduce the hipervolemia and the high pressure suffered by the portal system.
These shunts, however, led to an exaggerated loss of blood flow in the portal vein and, consequently, worsening the liver insufficiency, with the appearance of hepatic encefalopathy. The decompression of the portal system could lead to reduction of esophageal and gastric varices, protecting the patients of new and potentially fatal hemorrhage ${ }^{3}$.

Teixeira et al..$^{4}$ and Warren et al. ${ }^{5}$ developed a selective veno-venous shunt, using the splenic vein and the renal vein, named distal splenorenal shunt. The technique used the splenic vein, in its 
distal portion, anastomosing it with the left renal vein, in a terminal-lateral shape. The objective of this new technique was the decompression of esophageal veins, through the short gastric veins and spleen, to a system of lower pressure (inferior vena cava system), preventing the diversion of the portal blood flow, from the liver to the systemic circulation. This reasoning, if valid, would prevent the loss of the portal blood flow and keep the flux of hepatotrophics substances to the liver ${ }^{5}$. The maintenance of the portal flow to the liver would allow the prevention of the encephalopathy, promote liver protection and keep a certain degree of venous hypertension in the portal system, with better protection of the shunt and reduction in the incidence of thrombosis.

The distal splenorenal shunt was widely accepted and many studies have been published demonstrating its viability, feasibility, effectiveness, indications, technical difficulties, hemodynamics effects, complications and results ${ }^{6-12}$.

Having observed the non-selectivity of the distal splenorenal shunt, Warren et al. ${ }^{13}$ has published a modification in the technique that included the complete disconnection of the splenic vein from the pancreas and the section of the splenocolic ligament. The purpose of this technique is the interruption of blood flow to collateral splenic and peri-pancreatic veins that flow to the splenic vein. These collaterals, if not interrupted, lead to an escape of blood in the hepatofugal direction promoting hepatic encephalopathy. This lack of selectivity has been registered for Kanaya and Katoh ${ }^{14}$ even when the distal splenorenal shunt was associated with the splenopancreatic disconnection, suggesting that to obtain this selectivity, it would be necessary an association of a gastric disconnection to the previous technique. The gastric disconnection includes the section of the greater and lesser omentum. According to these authors, this technique demonstrates the capability of keeping the selectivity and portal blood flow to the liver.

With more studies on this technique and a larger world-wide casuistry, new questions have surfaced with regard to the continuity of the selectivity of the distal splenorenal shunt. It was observed that a gradual loss of portal blood flow, through development of collateral circulation through pancreatic, gastric and mesocolic veins, occurred. The number of papers confirming the non-selectivity of the distal splenorenal shunt increased although they have not been associated with facts that could explain such loss of selectivity.

The absence of anatomical explanation for such fact stimulated the research of the venous affluence from the pancreas to the splenic vein, with the objective to find a collateral circulation that could explain the loss of selectivity of the distal splenorenal shunt.

\section{Methods}

Thirty-eight anatomical pieces obtained from fresh human corpses that entered the Department of Morphology of the Superior School of Sciences of Santa Casa de Misericórdia de Vitória, supported in the Law n ${ }^{\circ} 8105$ of November 1992, victims of violent death were studied. All corpses that presented traumatic abdominal injuries of any nature were excluded. In relation to sexual gender thirty-six were male (94.74\%) and two, female (5.26\%). In relation to ethnical group nine were white $(23.68 \%)$ and twentynine were black $(76.32 \%)$. The age varied from 15 to 67 years of age, with an average of 29,24 $\pm 10,03$ years old.

The anatomical pieces were numbered sequentially upon arrival according to the order of the bodies. They were removed in standardized way and included the liver pediculum, abdominal esophagus, stomach, duodenum, pancreas, spleen and transverse colon. It was necessary to do that in order to permit the main components of the portal system to be analyzed.

After the anatomical piece was removed, the portal vein and the superior mesenteric vein were identified. In the first one, it was introduced a metallic cannula of $8 \mathrm{~mm}$ and then it was fixed to the vein, by means of a cotton thread. The superior mesenteric vein was ligated. Through the cannula, water was injected in the order to remove blood residues from the veins of greater and lesser caliber. After the exit of clean water from the veins, the mesenteric venous branches and all sectioned veins were ligated until no more water leak occurred. After all veins were tied up, the spleen and the splenic vein were compressed, in order to remove the residual water. After that, five to the $10 \mathrm{~cm}^{3}$ of pure acetone was injected through the cannula. Acetone is the diluent of the vinilic resin used in the preparation of the molds and was used, in this phase, with the objective to dehydrate the venous stream and to facilitate the progression of the resin up to the venules. The amount of acetone varied in accordance with the total capacity of the venous stream and was infused until the splenic vein became engorged. Following the injection of acetone, the infusion of the vinilic resin (VYAA), colored with Prussian blue, was set. The total infusion of the resin varied from $20 \mathrm{~cm}^{3}$ to $35 \mathrm{~cm}^{3}$, and the volume was considered satisfactory when it had filled up the spleen and venous branches of the greater and lesser curvature of the stomach. After the complete filling of the veins with the resin, the cannula was taken away and portal vein was ligated immediately. At this moment, it was possible to identify the left gastric and left gastro-epiploic veins, with resin in its interior. After this, the anatomical piece was left immersed in water for 24 hours, an acceptable period for the resin polymerization and formation of a mold of the filled veins. After that, the piece was immersed in commercial hydrochloric acid, for the corrosion of all the organic tissue. The corrosion process lasted between 48 and 72 hours, depending on the amount of organic tissue. After this period, the mold was washed in current water, without direct jet, to take away all the residues of organic tissue. After that, the piece was left immersed in water with continuous renewal of water during a 24-hour period. This immersion was done to eliminate the residues of hydrochloric acid in the mold. Before being analyzed, the mold remained for some hours in drying process. The mold was composed of the venous branches of the duodenum, pancreas, spleen and stomach (Figure 1). The mold was analyzed in both anterior and posterior faces.

The statistical analysis of the sampling was made by the Epi Info program, Version 6.04b (Centers will be Disease Control and Prevention, Atlanta, Georgia, USA in January, 1997). It was used descriptive statistics for calculation of the number of pancreatic branches that flowed to the lienal vein. The results in percentage were associated to the $95 \%$ confidence interval for proportions.

\section{Results}

From the thirty-eight anatomical pieces analyzed, all presented pancreatic branches draining into the splenic vein (Figure 2). The number of these branches varied from seven to twenty-two (14.52 \pm 3.53$)$. 


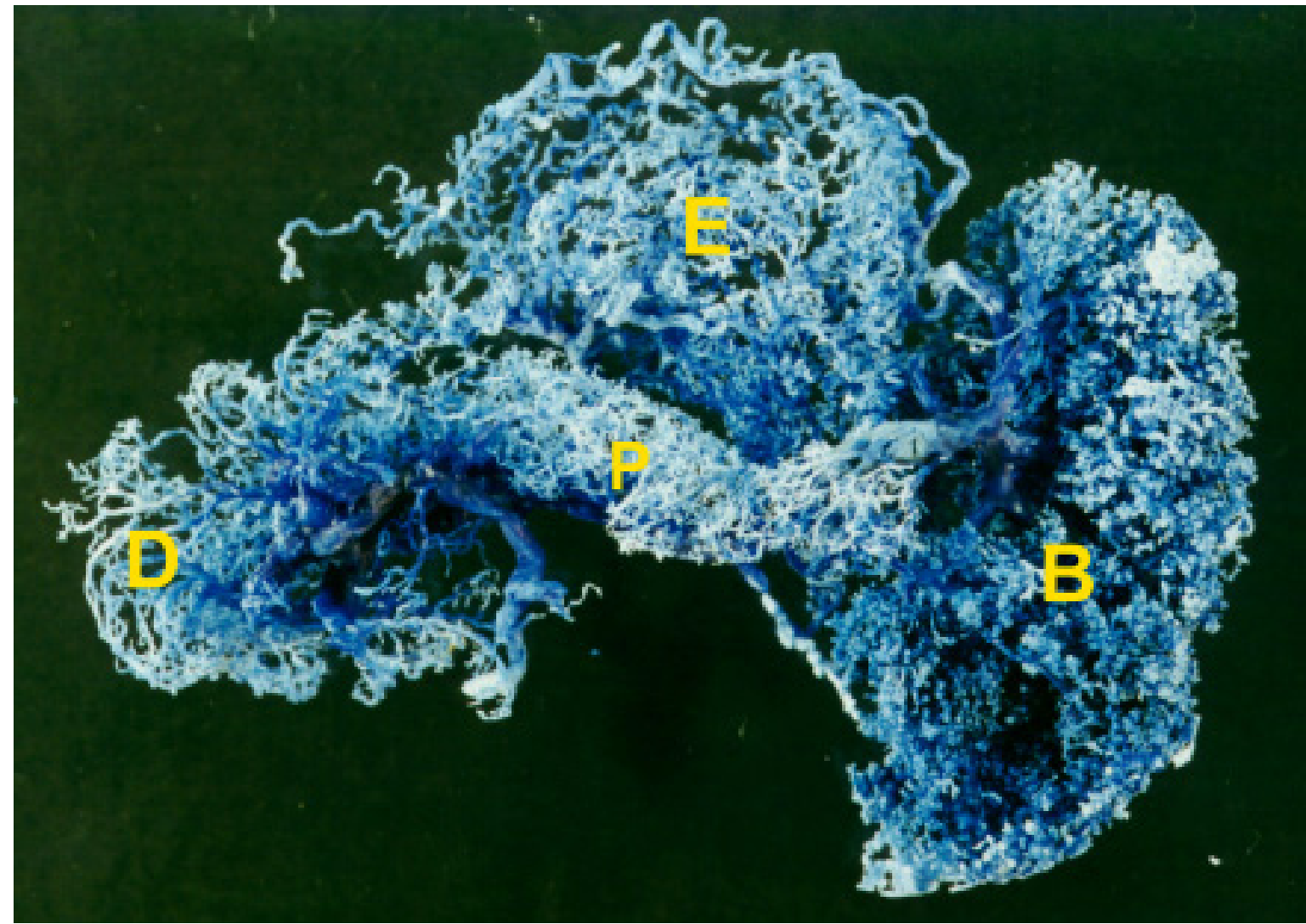

FIGURE 1 - Anterior view of venous vascular mold of the duodenum (D), pancreas (P), spleen (B) and stomach (E), after corrosion of the organic tissue in anatomical pieces of human beings

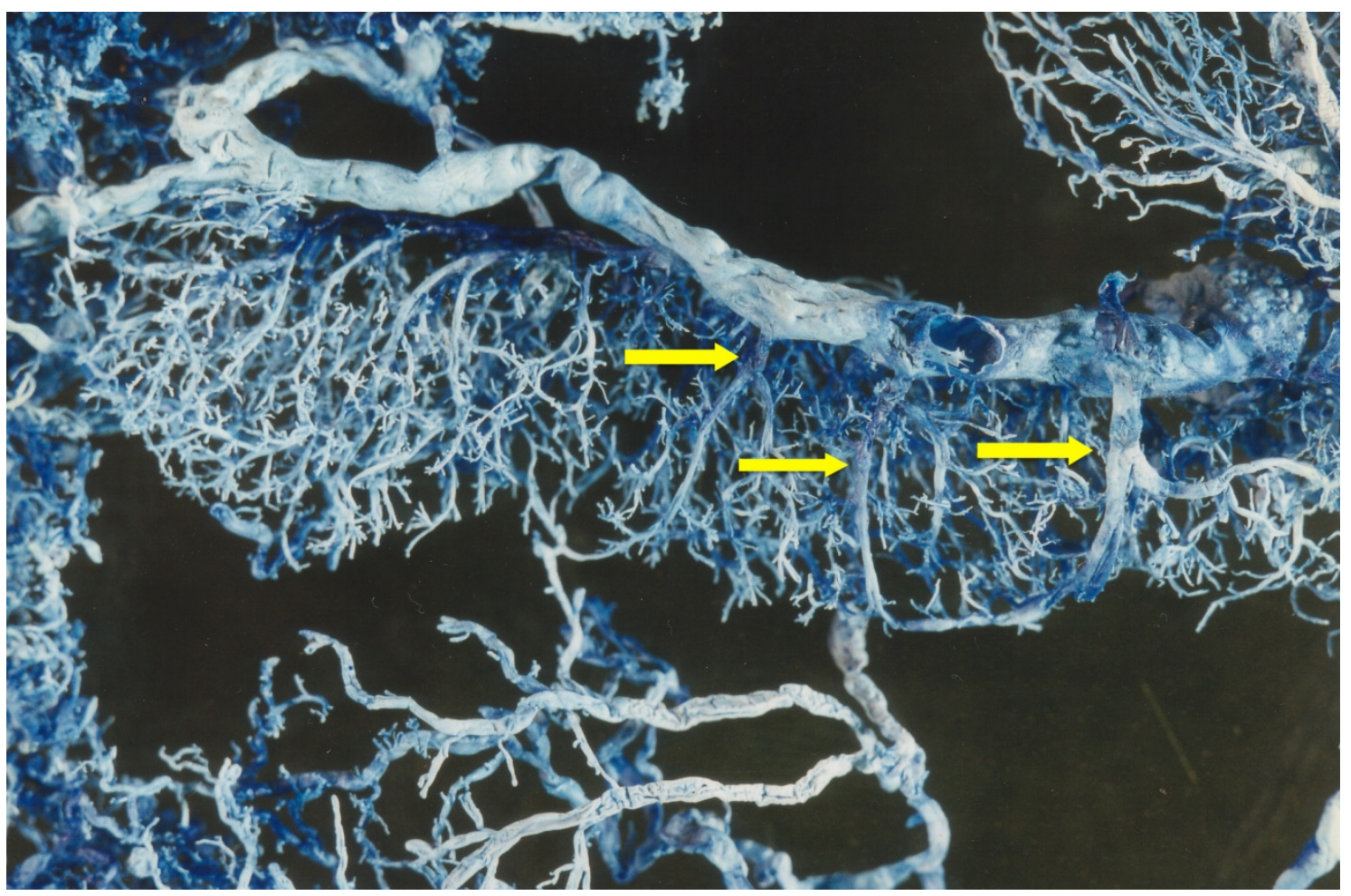

FIGURE 2 - Posterior view of the pancreatic venous vascular mold and affluent branches (arrows) to the splenic vein, in anatomical pieces of human beings 
Pancreatic branches proceeding from the tail of the pancreas that flowed to the segmentary splenic vein were present in 25 of the 38 studied pieces $(65.79 \%$ ) (Figure 3). The confidence interval of $95 \%$ for this proportion was of $50.74 \%$ to $80.84 \%$. These branches were one to four in number. We found one branch in fifteen pieces $(60 \%)$, two branches in six pieces $(24 \%)$, three branches in two pieces (8\%) and four branches in two pieces $(8 \%)$. The mentioned data are represented in Figure 4.

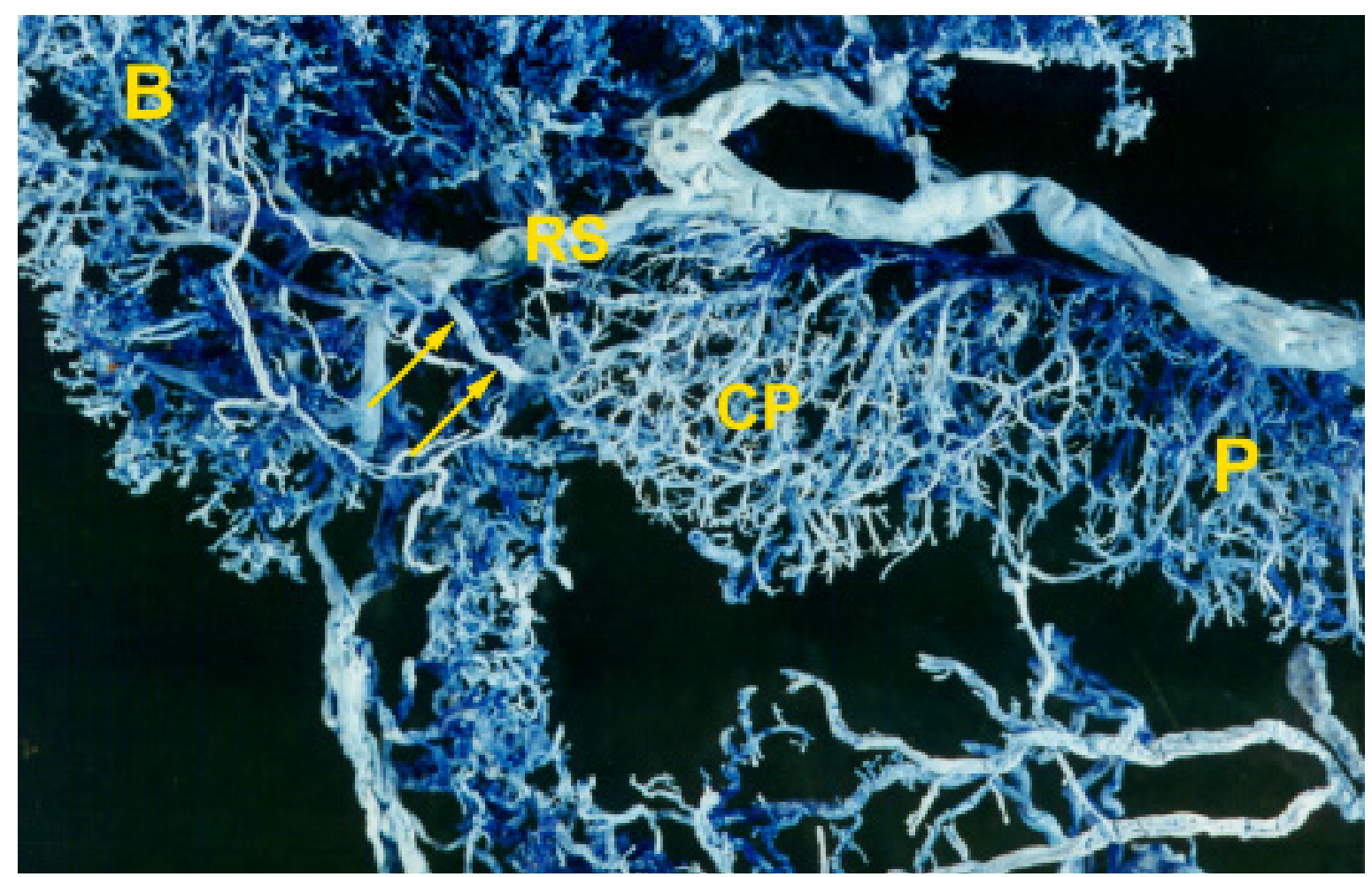

FIGURE 3 - Posterior view of venous pancreatic vascular mold after corrosion of the organic tissue in anatomical pieces of human beings. In this preparation we can observe a pancreatic branch (arrow), proceeding from the tail of the pancreas (P), draining into a segmentary branch of the splenic vein (RS)

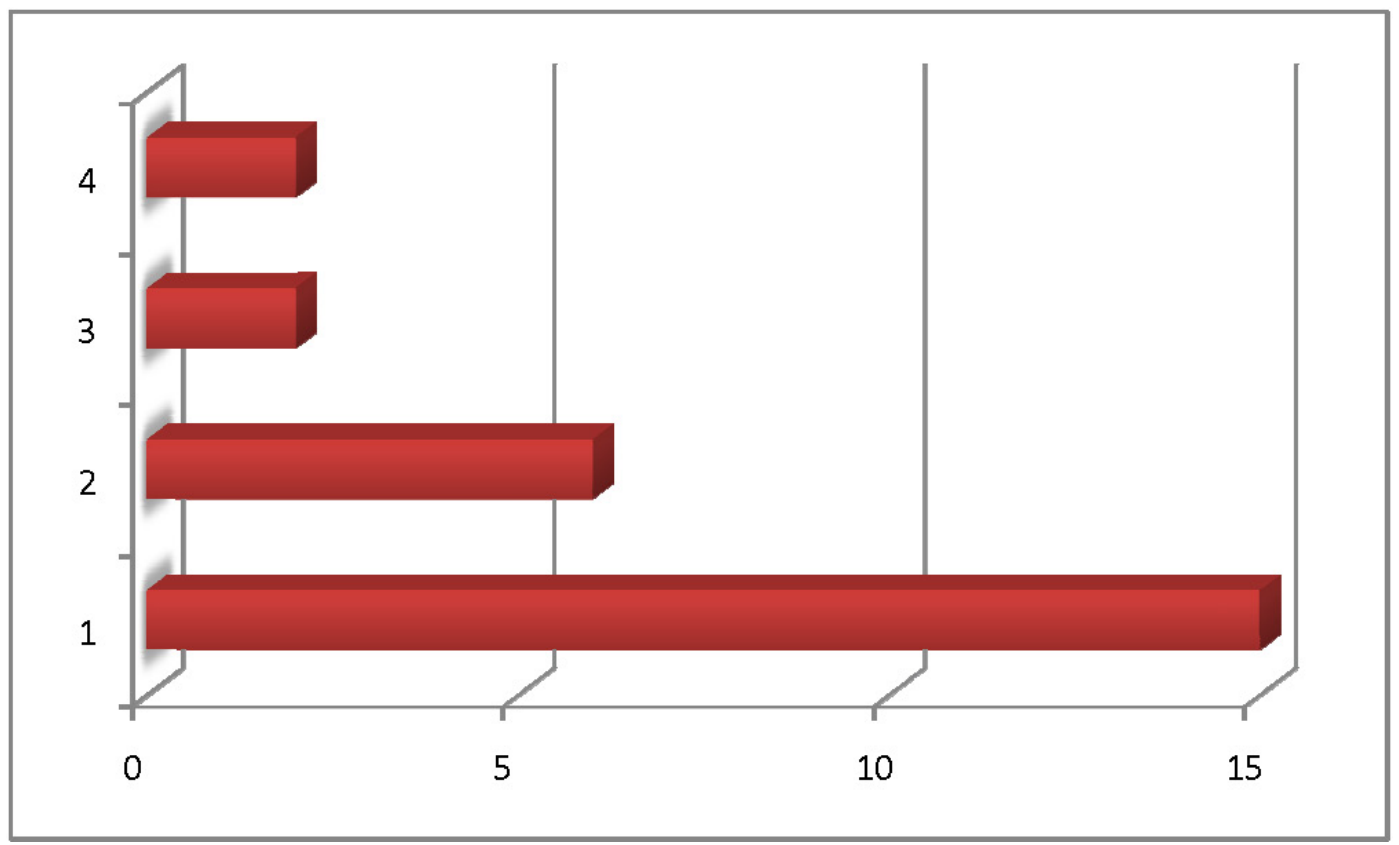

FIGURE 4 - Demonstrative graph of the number of pancreatics branches proceeding from the pancreatic tail (vertical axle) that drain into the lienal vein, and its frequency (horizontal axle) 


\section{Discussion}

Hypertension in the portal system is carried with the appearance of gastric and esophageal varices ${ }^{1,2}$. These would be the more important pathophysiological expression of portal hypertension syndrome. Regarding this syndrome Raia and Silva ${ }^{15}$ enhance its clinical and social value and affirm that this continues to be a therapeutical problem.

In the present time, despite of the possibility of treating portal hypertension in cirrhotic patients with the hepatic transplant, this procedure is not done in all nationwide territory nor is it indicated for all patients. Surgical shunts are, therefore, a therapeutical possibility for patients with portal hypertension of many causes. Among them, the distal splenorenal shunt is considered by some authors as a safe, lasting and effective procedure in the control of the hemorrhagic recurrence. It has lesser morbility, lesser loss of portal flow, lesser incidence of portal-systemic encephalopathy, better prognosis and does not compromise the future accomplishment of hepatic transplant, and it also delays the need for $i^{6-8}$.

Teixeira et al. ${ }^{4}$ and Warren et al. ${ }^{5}$ have developed a selective surgical technique of venous derivation. Teixeira et al. ${ }^{4}$ have conducted an experimental study in dogs, anastomosing the distal part of the splenic vein to the inferior vena cava. It has been possible, with this technique, to observe the drainage of the blood from the esophageal veins, through the short gastric veins, to the spleen. In such a way it would be possible to decompress the esophageal varices, keeping the mesenteric blood flow to the liver. Warren et al. ${ }^{5}$ has done an experimental and clinical study in which the distal part of the splenic vein was anastomosed to the inferior vena cava, in the experimental study, or to the left renal vein, in the clinical study. The objective of this experiment was to decompress the gastroesphageal varices, through the spleen, in a selective way. The observed results indicated the viability of using the spleen as an escape way for the varices of the esophagus and gastric fundus, keeping the venous portal perfusion to the liver and a high pressure in the intestinal stream bed. This selective procedure, according to some authors, would give similar hepatic protection than the non-shunt procedures, without presenting the high incidence of bleeding recurrence, frequently observed in nonshunt procedures.

Although its low morbidity, the distal splenorenal shunt did not maintain its selectivity, with more studies on this technique and with a greater world-wide experience, new questions have been asked regarding the continuity of the selectivity of the distal splenorenal shunt. Therefore, a gradual diversion of portal flow from the liver, through pancreatic, gastric and mesentery collaterals occurred. The number of publications confirming the nonselectivity in the distal splenorenal shunt has been increasing, although they have not been associated to facts that could explain such loss of selectivity.

Salam and Warren ${ }^{16}$ alerted for the necessity to proceed to an effective disconnection of the splenic and superior mesenteric compartments in order to preserve the selectivity of the distal splenorenal shunt. Warren et al. ${ }^{13}$ observed the diversion of portal flow in cirrhotic patients, submitted to the distal splenorenal shunt that could be attributed to the development of colonic and pancreatic collaterals. Accordingly to the authors, modifications in the distal splenorenal shunt technique must be done with the objective to preserve the portal flow to the liver. The modification consisted of the complete disconnection of the splenic vein and the section of the splenocolic ligament. To confirm the effectiveness of the modified technique, the authors have done a comparative study between the distal splenorenal shunt with and without the splenic disconnection. The results allowed the authors to conclude that the complete disconnection of the splenic vein and the section of the splenocolic ligament could prevent the development of a pancreatic siphon, resulting in the maintenance of the portal flow to the liver. Katoh et al. ${ }^{17}$ has described a similar technique, with the complete disconnection of the pancreatic body and tail, and found inferior levels of encefalopathy than those registered in the literature.

The complete release of the splenic vein, with the section of all its pancreatic branches that drain into this vein, is justified anatomically for the real or potential presence of visceral affluents of the splenic vein that composes the peri-pancreatic venous circulation. All the anatomical pieces used in this study presented pancreatic branches draining into the splenic vein or its segmentary branches, in numbers that varied from seven to twenty and two. This release, in our opinion, would have to include the pancreas tail, at the level of splenic hilum, as mentioned by Katoh et $a l .{ }^{17}$. This operation complement has not been widely adopted until now probably due to the lack of knowledge of the existence of veins proceeding from the pancreatic tail that drain into the segmentary branches of the splenic vein, described in this paper. These branches were present in $65.79 \%$ of the anatomical pieces. They varied from one to four, with predominance of one or two branches. Considering the frequency that they had been found and their diverse passage from the pancreatic branches that drain to the splenic vein, the release of the pancreatic tail with ligation of such branches during the accomplishment of the splenopancreatic disconnection appears to be of great value.

It is well known that the selectivity of the distal splenorenal shunt, initially proposed, does not exist. It is also known that the failure or the inefficiency of a venous anastomosis facilitate the development of collateral circulation and the diversion of portal flow to splanchnic veins, including the peri-pancreatic veins. Thus, in a condition of portal hypertension not controlled at physiological levels, varices could be generated in this collateral system, facilitating the portal-systemic encepalophaty that the distal splenorenal shunt itself was not completely predicted.

Considering the observed results and also considering the incapacity to solve the problem of the ideal affluence to the portal system in hypertensive conditions, something can be suggested. An approach of the peri-pancreatic venous branches that could increase the effectiveness of splenorenal shunt and maintain the venous flow to the portal vein. Hindering of the formation of pancreatic siphon would occur a lower incidence of portal-systemic encephalopathy and hepatic insufficiency, complications of great relevance in patients with schistosomiasis, so frequent in our country, that have a good functional capacity of the liver.

\section{Conclusions}

In $65.79 \%$ of the anatomical pieces studied, the veins of the pancreatic tail flowed in segmentary branches of the splenic vein. These branches could be responsible for the loss of distal splenorenal shunt selectivity. The complete disconnection of the pancreatic tail could increase the selectivity in this procedure. 


\section{References}

1. Brandt CT, Tavares Maciel DS, Caneca OAF. Splenectomy associated with ligature of the left gastric vein in children with surgical schistosomiasis: analysis of the hepatic functional reserve. Acta Cir Bras. 1997;12(3):150-3. 2. Goldenberg S. Varizes gástricas. Retrospectiva na esquistossomose mansônica hepato-esplênica. Acta Cir Bras. 2003;18(3):172-7.

3. Abdala P. Hepatosplenopatia esquistossomótica e hemorragias digestivas: seu tratamento cirúrgico e de emergência. J Bras Med. 1965;9(6):655-69. 4. Teixeira ED, Yu H, Bergan JJ. Nova técnica na cirurgia da hipertensão portal: estudo experimental. Rev Bras Cir. 1967;53:443-6.

5. Warren WD, Zeppa R, Fomon JJ. Selective trans-splenic decompression of gastroesophageal varices by distal splenorenal shunt. Ann Surg. 1967;166(1):437-55.

6. Rikkers LF, Rudman D, Galambos JT, Fulenwider JT, Millikan WJ, Kutner M, Smith III RB, Salam AA, Jones Jr. PJ, Warren WD. A randomized, controlled, trial of distal splenorenal shunt. Ann Surg. 1978;188(3):271-80.

7. Jenkins RL, Gedaly R, Pomposeli JJ, Pomfret EA, Gordon F, Lewis WD. Distal splenorenal shunt. Role, indications, and utility in the era of liver transplantation. Arch Surg. 1999;134:416-20.

8. Livingstone AS, Koniaris LG, Perez EA, Alvarez N, Levi JU, Hutson DG. 507 Warren-Zeppa distal splenorrenal shunt. A 34-year experience. Ann Surg. 2006;243(6):884-94.

9. Wright AS, Rikkers LF. Current management of portal hypertension. J Gastrointest Surg. 2005;9(7):992-1005.

10. Henderson JM, Boyer TD, Kutner MH, Galloway JR, Rikkers LF, Jeffers LJ, Abu-Elmagd K, Connor J. Distal esplenorenal shunt versus transjugular intrahepatic portal systematic shunt for variceal bleeding: a randomized trial. Gastroenterology. 2006;130(6):1643-51.

11. Santambrogio R, Opocher E, Costa M, Bruno S, Ceretti AP, Spina GP. Natural history of a randomized trial comparing distal spleno-renal shunt with endoscopic sclerotherapy in the prevention of variceal rebleeding: a lesson from the past. World J Gastroenterol. 2006;12(39):6331-8.
12. Orozco H, Mercado MA, Takahashi T, Garcia-Tsao G, Guevara L, Hernandez Ortiz J, Hernandez-Cendejas A, Tielve M. Role of the distal splenorenal shunt in management of variceal bleeding in Latin America. Am J Surg. 1990;160(1):86-9.

13. Warren WD, Millikan WJ Jr, Henderson JM, Abu-Elmagd KM, Galloway JR, Shires GT 3rd, Richards WO, Salam AA, Kutner MH. Splenopancreatic disconnection: improved selectivity of distal splenorenal shunt. Ann Surg. 1986;204(4):346-55.

14. Kanaya S, Katoh H. Long-term evaluation of distal splenorenal shunt with splenopancreatic and gastric disconnection. Surgery. 1995;118(1):29-35.

15. Raia S, da Silva AT, Lopes JD, Mies S, de Oliveira e Silva A, Straus E, Laudanna A, Raia A, da Silva LC. Descompressão portal seletiva por anastomose esplenorrenal distal para tratamento das varizes hemorrágicas do esôfago na esquistossomose mansônica. Rev Hosp Clin Fac Med Sao Paulo. 1971;26(4):149-52.

16. Salam AA, Warren WD. Anatomic basis of the surgical treatment of portal hypertension. Surg Clin North Am. 1974;54(6):1247-57.

17. Katoh H, Shimozawa E, Kojima T, Tanabe T. Modified splenorenal shunt with splenopancreatic disconnection. Surgery. 1989;106(5): 920-4.

\section{Acknowledgment}

To the Department for Support of Clinical and Experimental Research of the Institute for Sustainable Development (Instituto Solidário do Espírito Santo) for financial support.

\section{Correspondence:}

Claudio Piras

Rua Alaor de Queiróz Araújo, 175/602

29055-010 Vitória - ES Brazil

Phone: (55 27)3222-1545 / 9989-8280

danilo.vix@terra.com.br

Conflict of interest: none Financial source: In acknowledgment

\section{How to cite this article}

Piras C, Paulo DNS, Paulo ICAL, Rodrigues H, Lázaro da Silva A. Venous drainage from the tail of the pancreas to the lienal vein and its relationship with the distal splenorenal shunt selectivity. Acta Cir Bras [serial on the Internet], 2010 Jan-Feb; 25(1). Available from URL: http://www.scielo.br/acb 